\title{
REVIEW: FRUITS OF MORINDA CITRIFOLIA
}

\author{
PRADEEPA PRASAD, VISAGAPERUMAL,AHAMED ZONOUBI, \\ AND VINEETH CHANDY \\ DEPARTMENT OF PHARMACEUTICAL CHEMISTRY, T.JOHN COLLEGE OF \\ PHARMACY, BENGALURU, KARNATAKA, INDIA
}

ABSTRACT
This review was conducted to investigate the phytochemistry and pharmacological properties of Morinda citrifolia. The study was carried out by searching for keywords Morinda citrifolia L, noni, phytochemical Components and biological activity in different scientific articles and books published in various search engines like PubMed, science direct etc. M. citrifolia is commonly known as Indian mulberry, Chessy fruit or Noni in India.. M. citrifolia has a wide range of therapeutical uses such as arthritis, burns, headache, wounds and skin infections. The parts including fruits, seeds, barks, leaves, and flowers has their own individual nutritional and therapeutical values. However, the fruits of noni has been considered as the most important part which contain more number of chemical compounds. The major phytochemical components found to be phenolic compounds, anthraquinones, organic acids, beta-carotenoids, terpenoids, alkaloids, non-volatile and volatile components.

KEY WORDS: Morinda citrifolia L, Phytochemical Components, Biological Activity.

\section{INTRODUCTION:}

Ancient Ayurvedic texts cite Noni as Ashyuka, which in Sanskrit means 'longevity'. Morinda citrifolia, had been used as a food supplement and health enchancher, commonly known as Noni or Indian mulberry. Ancient Polynesians used raw noni fruit, internally and externally, to maintain good health and heal a variety of ailments. It has been reported that Morinda citrifolia has a wide range of therapeutic uses in ailments such as arthritis, burns, headache, wounds and skin infections ${ }^{1}$.In the European Union, after safety testing on one particular brand of noni juice (Tahitian Noni), approval was granted in 2002 as a novel food by the European Commission for Health and Consumer Protection Directorate-General ${ }^{2}$. Morinda citrifolia known as Indian Mulberry or Noni which belonging to the family Rubiaceae. Mainly these species are cultivated in the tropical regions of Southeast Asia and Australasia. Interestingly, there are around 100 names of this fruit around different regions in the world.

\section{HISTORY}

The history of this small little green fruit dates back to the ancient era of Ayurveda. Various books has reported the health benefits of noni. Australasia,South East \& Southern part of Asia and Pacific islands are some parts of the world which uses noni as health enchaner. As per a few ancient manuscripts, noni fruit is loaded with natural healing agents, which can easily cure various diseases with regular consumption in the right proportions. Even after so many years, this fruit has been used to treat and prevent various health problems.

Biological source:-Noni is the fruit, leaves, bark, roots and the whole tree of morinda citrifolia belonging to the family Rubiaceae. 


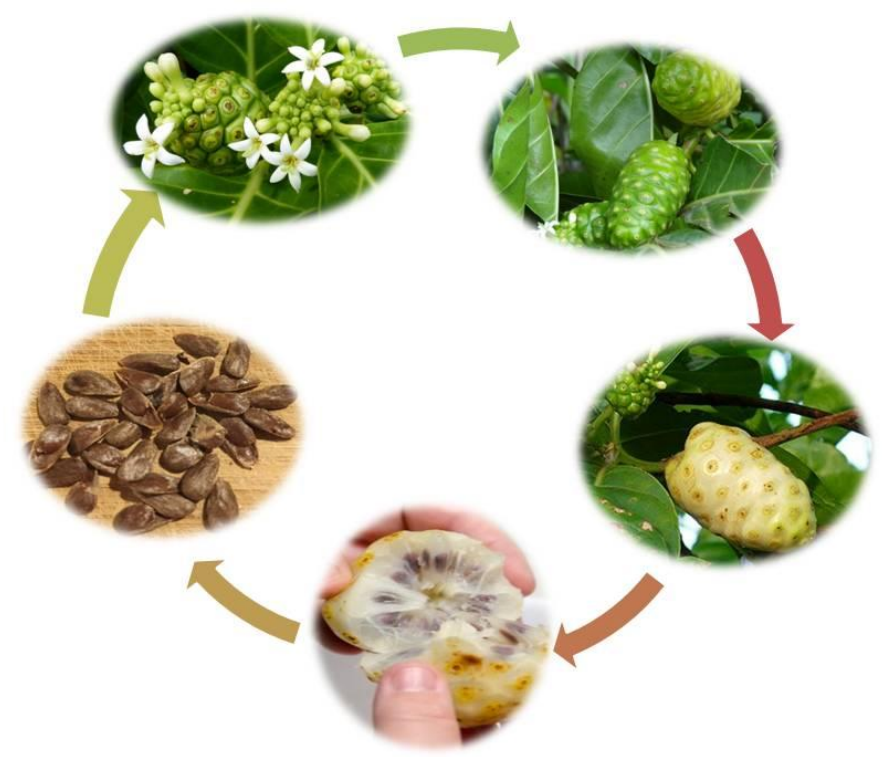

Other features: -Noni is a small tree which grows around 10 to 30 feet in height. It has bright green, thick, deeply veined and elliptical leaves. It has fruits with unusual shapes and about 3 to 5 inches in length and 10 to $18 \mathrm{~cm}$ in size and ovoid. Fruit contains lots of seeds. The tree has flowers and fruits throughout the year. The immature fruit is hard in nature with dark green color and later it turns to light yellow to white as it ripens. And when ripens, it has an unpleasant odor and become tender at maturity. Because the fruit has an unpleasant odor, it is also known as cheesy fruit or even vomit fruit.

\section{CHEMICAL CONSTITUTION.}

Noni (Morinda citrifolia L.) is known for manifold health benefits. Around 200 bioactive compounds were reported in Noni but their kind and concentration varies with plant parts, genotypes, environmental factors and estimation methods. Researchers isolated ninety six volatile components from Noni fruit at two different ripening stages (ripe and over ripe). Two unsaturated esters 3-methyl-3-buten-1-yl hexanoate and 3-methyl- 3-buten-1-yl octanoate significantly decreased in their concentrations in the ripe to over-ripe fruits ${ }^{3}$. Ripened fruit showed significantly higher amounts of volatile components, aldehydes, ketones, esters, alcohols, terpenes and sulphur compounds like methyl hexanoate, methyl octanoate, ethyl octanoate and methyl 4 E-decenoate etc, (table:1), while octanoic acid and decanoic acid concentrations were significantly lower.

\begin{tabular}{|l|l|}
\hline Acids & $\begin{array}{l}\text { Formic acid, Acetic acid, Butanoic acid, Hexanoic acid, Heptanoic acid, } \\
\text { Octanoic acid, 2-octanoic acid, Nonaoic acid, Decanoic acid }\end{array}$ \\
\hline Alcohols & $\begin{array}{l}\text { Ethanol, 2-methyle-3-buten-1-ol, 1-butanol, 3-Methyl-3-buten-1-ol, 3- } \\
\text { Methyl-2-buten-1-ol, Benzyl alcohol }\end{array}$ \\
\hline Esters & $\begin{array}{l}\text { Ethyl acetate, Butyl acetate, Methyl 2-methylepropanoate, Methyl } \\
\text { butanoate, Ethyl butanoate, Butyl butanoate, Methyl 3-methylbutanoate, } \\
\text { 4-Pentenyl butanoate, 3-Methyl-3-buten-1-yl 3-methylbutanoate, Methyl } \\
\text { 2-methylbutanoate, Methyl hexanoate, Methyl 2-methylbutanoate, } \\
\text { Methylehexanoate, Ethyl hexanoate, Butyl hexanoate, 4-pentanyl } \\
\text { hexanoate, 3-Methyl-3-buten-1- yl hexanoate, Hexyl isovalerate, Methyl } \\
\text { heptanoate, Methyl octanoate, Ethyl octanoate, Butyl octanoate, 3- } \\
\text { Methyl-3-buten-1-yl octanoate, Methyl 2-octenoate, Methyl 3-octenoate, }\end{array}$ \\
\hline
\end{tabular}




\begin{tabular}{|l|ll|}
\hline \hline & $\begin{array}{l}\text { Methyl 3-octenoate, Methyl nonanate, Methyl 5-nonanate, Methyl } \\
\text { decanoate, Ethyl decanoate, Methyl 4-decanoate, Ethyl 4-decanoate, } \\
\text { Methyl salicylate, Methyl hexadecanoate }\end{array}$ \\
\hline Terpenes & $\begin{array}{l}\text { Linalool oxide, (Z)-3,7-Dimethyl-1,3,6-octatriene, (+)-4-Carene, D- } \\
\text { Limonene, Ocimenol, Terpineol }\end{array}$ \\
\hline $\begin{array}{l}\text { Sulfur } \\
\text { Compounds }\end{array}$ & $\begin{array}{l}\text { Methanethiol, S-Methyl thioacetate, Dimethyl disulfide, Methyl 3- } \\
\text { methylthiopropanoate, Ethyl 3-methylthiopropanoate, } \\
\text { methylthiopropanoic acid 3- }\end{array}$ \\
\hline $\begin{array}{l}\text { Aldehydes and } \\
\text { ketones }\end{array}$ & $\begin{array}{l}\text { Acetaldehyde, 2-methylebutanol, 3-methylebutanal, 2-pentanone, 3- } \\
\text { methyle-2-butanone, 2-hexanone, 2-Hexenal, Furfural, Benzaldehyde }\end{array}$ \\
\hline
\end{tabular}

This suggested that the presence of sulphur contributes to the flavour characteristics of Noni juice(SPME and SDE methods) ${ }^{4}$. It was suggested that the production process (fermentation and juice vs drying or lyophilization) has no effect on the anthraquinone content. In ripe fruit there is no as such influence on anthraquinone content. The fruit pulp contain polydatin and mature fruit contain anthraglycoside B. It has been reported that immature fruit is not ideal for therapeutic applications as only two phytochemical substances (polydatin and ácryptoxanthin) were present(D.R. Singh et al,2012) ${ }^{5}$. Commercial Noni products in the market whether fermented or unfermented juice or powder should be obtained from fully ripe Noni fruits and seed should be removed during drying process ${ }^{6}$. Compared the Total Phenolic Content (TPC) of commercial Noni juice with blueberry and grape juice, reported that Noni juice contains $65.56 \%$ of total polyphenols against $27.90 \%$ and $6.54 \%$ which represent the $5 \%$ blueberry and grape juice, respectively. Blue berry and grape juice mask the unpleasant odour and bitter taste of Noni fruit juice and allows alteration in the organoleptic properties of commercialized Noni juice. Commercial Noni juice presented higher values of TPC (91.90 $\mathrm{mg}$ of gallic acid/100 ml juice) and antioxidant activity $(5.85 \mathrm{mmol} / \mathrm{L})$ when compared to its $5 \%$ diluted constituents. Regarding the antioxidant activity of noni juice and its components, it was observed that $64.27 \%$ of antioxidant activity could be represented by noni juice, and $29.40 \%$ and 6.32 by $5 \%$ diluted blueberry and grape juices, respectively ${ }^{7}$. Identified polyphenols belonging to the coumarin, flavonoid and phenolic acid groups, and two iridoids in Noni juice by HPLC-DAD and Electro Spray Ionization Mass Spectrometric detection (HPLC-ESI-MS) method.

Fermented fruit extract contain micronutrients, non-volatile and volatile components, ketones, lactones, beta-carotenoids, terpenoids, proxeronine. ${ }^{8}$ Physicochemical, phytochemical and antimicrobial properties of Noni fruit collected at different maturity levels were investigated. The results showed the maximum antibacterial activity in ethanolic extract of mature Noni fruit against $K$. Pneumonia $(21 \mathrm{~mm})$ whereas in methanolic extract of mature Noni fruit showed maximum antifungal activity against $A$. Flavous $(19 \mathrm{~mm}){ }^{9}$

\section{Mechanism of action of phytoconstituents present in various parts of Noni plant Damnacanthal}

Damnacanthal, an anthraquinone induced normal morphology and cytoskletal structure in Kras NRK cells at the tolerant temperature without changing the amount and localization of ras. The effect of damnacanthal was reversible and had not shown any effect on the morphology of RSVTs-NRK cells states the src oncogene. Hence, damnacanthal is a new inhibitor of ras function. ${ }^{10}$ The MTT method confirmed that damnacanthal inhibitor the growth of MCF-7 cells at the concentration of $8.2 \mu \mathrm{g} / \mathrm{ml}$ for $72 \mathrm{~h}$. Moreover, damnacanthal was found to induce cell cycle (CC) arrest at the G1 check point in MCF-7 cells by CC analysis. The result provided significant evidence in demonstrating that p53-mediated damnacanthal induced apoptosis through the activation of $\mathrm{p} 21$ and caspase- $7 .^{11}$ 
In another study, it was reported that damnacanthal acts against Hep G2 hepatocellular carcinoma cells by decreasing the phosphorylation level of Akt and targets matrix metalloproteinase-2 secretion in Hep G2 cells. ${ }^{12}$ Reported that the damnacanthal possesses strong inhibitory activity towards tyrosine kinases i.e. Lck, Src, Lyn and EGF receptor. ${ }^{13}$

Epigallocatechin gallate ( $E G C G)$

EGCG present in Noni which is known for its potent antioxidant and antiangeogenesis activity also it inhibits the quinol oxidase (NOX) enzyme, which is responsible for tumor activity. Thus, Noni helps in antiangiogenesis by inhibiting NOX. ${ }^{14}$

\section{Alizarin and limonene}

Found to inhibit the formation of blood vessels over the tumor by antiangeogenesis property. Thus Noni juice inhibit the growth and mutations of malignant cells and induce programmed cell death or apoptosis. ${ }^{15}$

\section{Polysaccharides}

Glucoronic acid, galactose, arabinose, rhamnose, glycosides and trisaccharide fatty acid ester showed immuno-stimulatory, immune-modulatory, antibacterial, antitumor and anticancer activity. ${ }^{16}$ 6-D-Glucopyranose pentaacetate is sulphated polysaccharides, which undermine the interaction between glucosaminoglycan and certain proteins. This helps to block the ability of mutated cells to adhere to new cells stopping metastasis. ${ }^{17}$

Compounds present in Noni fruit like iridoid glycosides, 6-alpha hydroxyadoxoside, 6 beta, 7-beta-epoxy-8-episplenoside as well as americanin, narcissoside, asperuloside, asperulosidic acid, citrifolin Bepimera, borreriagenin, deacetylasperuloside, dehydromethoxy gaertneroside, cytidine, epi-dihydrocornin, d-glucose, d-mannitol, methyl alpha-dfructofuranoside, methyl beta-d-fructofuranoside, nicotifloroside, and beta-sitosterol 3-Obeta-d-glucopyranoside showed antioxidant activity in both DPPH and NO2 reducing activity bioassays. ${ }^{18}$ Researcher's states that Noni has good antioxidant activity, having free radical scavenging activity and quenching lipid peroxides. ${ }^{19}$

\section{Quercetin}

Reported decreased cell viability of both low metastatic cell line ACC-2 and high metastatic cell line ACC-M with quercetin treatment in a concentration and time dependent manner. Quercetin significantly decreases the apoptosis in ACC cells through a mitochondria dependent pathway which showed close correlation with down regulation of the PI3K/Akt/IKKalpha/NF-kappaB pathway. Their result reveals that quercetin may be a hopeful chemotherapeutic agent against ACC through its function of down regulating the $\mathrm{PI} 3 \mathrm{~K} / \mathrm{Akt} / \mathrm{IKK}$-alpha/NF-kappaB signaling pathway. ${ }^{20}$

\section{$\underline{\text { Scopoletin }}$}

Scopoletin decreases carrageen induced iNOS and COX-2 expressions in the paw edema. These anti-inflammatory mechanisms of scopoletin may be related to the reduced in the level of MDA via increasing the activities of SOD, GPX and CAT in the paw edema. ${ }^{21}$

Anthraquinones, saponins and scopoletin were identified by TLC techniques and their Rf value were determined. ${ }^{27}$

\section{$\underline{\text { Xeronine }}$}

Noni fruit contain proxeronine which combine with proxeroninase an enzyme present in the body to form xeronine which may help to enlarge the pore size of the tumor cells and allow 
anticancer drugs to enter the cells more easily. Also, xeronine increases the permeability of $\mathrm{K}+\mathrm{ions}$ and prevent the formation of lactic acid from glucose. ${ }^{12}$

\section{$\underline{\text { Citrifolinoside }}$}

Citrifolinoside isolated from the leaves of $M$. citrifolia plant showed significant inhibition of UVB-induced Activator Protein-1 (AP-1) activity in cell cultures. ${ }^{22}$

\section{Monoterpene}

A monoterpene, limonene present in Noni fruit has been shown to prevent mammary, liver, lung and other cancers. Limonene stimulate thymus gland to secrete more $\mathrm{T}$ cells which destroy the carcinoma cells. ${ }^{23}$

\section{Beta carotene}

Suggested that beta carotene reduced the oxygen free radical and prevent oxidative damage. Also reported that long term use of moderate dose of $\beta$-carotene significantly reduced prostate cancer incidence in male smokers. ${ }^{24}$

\section{$\underline{\text { Ursolic acid }}$}

It possess anti-carcinogenic effect both externally and internally prevent growth of cancerous cells and induce apoptosis by modulating immune process of the body. ${ }^{25}$

\section{$\underline{\text { Gallic acid }}$}

Gallic acid reduced compound 48/80-or immunoglobulin E (IgE) which induced histamine release from mast cells. The inhibitory effect of gallic acid on the histamine release was mediated by the modulation of cAMP and intracellular calcium. Gallic acid decreased the phorbol 12-myristate 13-acetate and calcium ionophore A23187-stimulated pro-inflammatory cytokine gene expression and production such as TNF-a and IL-6 in human mast cells. ${ }^{26}$

\section{BIOLOGICAL ACTIVITY}

According to the European Commission 5th framework program quality of life, there are no systematic reviews or metaanalyses that have been published about the $\mathrm{M}$. citrifolia wide ranges of therapeutical claims (Pilkington and The CAMCancer Consortium, 2015). In the next paragraph, the discussed therapeutic indications are linked to a clear scientific evidence of either in vitro and in vivo studies, or clinical trials, with a specification about the responsible phytochemical component of each activity, as well as the extracting solvent and the used part of the plant along with its country of origin.

\section{Antifungal activity}

Jayaraman et al., has reported that the antifungal properties of Indian M. citrifolia fruit extract in three different solvents, methanol, ethyl acetate and hexane were tested in an in vitro assay on different fungi including Candida albicans, Aspergillus niger, Trichophyton mentagrophytes, Penicillium species, Fusarium species, Aspergillus fumigates, Rhizopus species, Aspergillus flavus, and Mucor species.The maximum inhibition was in the methanol and ethyl acetate extract of $79.3 \%$ and $62.06 \%$,respectively against Trichophyton mentagrophytes, while almost 50\% inhibition was recorded in the methanol extract against Penicillium, Fusarium and Rhizopus species, and none of the extracts were active against either Candida albicans or Aspergillus species ${ }^{28}$. Despite the fact that in vitro results for antibacterial and anti-fungal studies are promising yet further in vivo and clinical research are highly recommended using different routes of administrations. 
2. Antioxidant activity

Australian M. citrifolia fruit juice showed an anti-oxidant activity 2.8 and 1.4 times higher than vitamin $\mathrm{C}$ and pycnogenol,respectively. This antioxidant activity was similar to grape seed powder at the daily dose recommended by U.S.RDAs and manufacturers ${ }^{29}$. Neolignan and americanin A were the potent antioxidant onstituent of the American M. citrifolia fruit ${ }^{30}$ (Su et al., 2005). The optimum magnitudes of radical scavenging activity (RSA), and total phenolic content of Malaysian seedless M. citrifolia fruit methanol extract were $55.60 \%$ and $43.18 \mathrm{mg} \mathrm{GAE} / 10 \mathrm{~g}$,respectively ${ }^{31}$. In other study, M. citrifolia anti-oxidant activity was evaluated as a natural antipigmentation agent by observing the effect of $50 \%$ ethanol extracts of Tahitian M. citrifolia fruit flesh, leaves, and seeds, on the tyrosinase enzyme responsible for controlling the production of melanin. The in vitro test was carried out using tyrosinase inhibitory assay, showing that seed extract had stronger tyrosinase inhibitory (from 20 to 500 $\mathrm{lg} / \mathrm{ml})$ and antioxidant activity than the fruit $(500 \mathrm{lg} / \mathrm{ml})$, while leaf extract did not have any tyrosinase inhibitory activity at any concentration. The tyrosinase inhibitory activity was linked to the presence of lignans in M. citrifolia, particularly 3,30-bis demethylpinoresinol and americanin $\mathrm{A}^{32}$. The same seed extract was found to have anti-photoaging activity at concentrations ranging from 0.5 to $1.0 \mathrm{mg} / \mathrm{ml}^{33}$ and also inhibited blood hemagglutination at concentrations ranging from 50 to $500 \mathrm{lg} / \mathrm{ml}^{34}$ ursolic acid was the responsible chemical for the both activities. M. citrifolia anti-oxidant property was also linked to other health enhancements activities. In an in vitro evaluation of methanol, chloroform, ethanol, butanol and aqueous extract of Indonesian M. citrifolia fruit, all extracts were able to inhibit Lowdensity lipoprotein (LDL) oxidation due to $\mathrm{M}$. citrifolia lignans, such as americanol A, americanin A, americanoicacid A, morindolin, and isoprincepin ${ }^{35}$. Other in vitro study suggested Malaysian M. citrifolia leaf ethanol extract was a highly effective natural antiobesity supplement than its fruit. Leaf and fruit methanol extracts inhibited the lipoprotein lipase activity $66 \% \pm 2.1$ and $54.5 \% \pm 2.5 \%$, respectively. Both extracts contain high levels of phenolic constituents including catechin, epicatechin and rutin which acted synergistically to demonstrate this activity ${ }^{36}$. Furthermore, Tahitian M. citrifolia juice was able to reduce obesity related to insulin resistance in an in vitro mouse muscle cells $\mathrm{C} 2 \mathrm{C} 12$ culture, by inhibiting the reactive oxygen species and mitochondrial damage ${ }^{37}$. A clinical study was carried out on twenty-two participants (16 women and 6 men), aged between 18 and 65 years old for 12 weeks trial of a weight-loss program with a fixed study factors including Tahitian M. citrifolia -based dietary supplements (US brand), daily calorie reduction, and exercise. All participants experienced weight loss with significant decrease in fat mass without side effects. However, the researchers suggested that further clinical studies should be carried out to include more male participants, and ethnic diversity ${ }^{38}$. Antidyslipidemia activity was related to M. citrifolia antioxidant property in the aqueous-ethanol extracts of its Indian fruits, leaves, and roots in Sprague-Dawley rats and mice of either sex, all these different parts extracts caused significant reduction in total cholesterol, triglyceride (TC), low density lipoprotein-cholesterol, atherogenic index and TC/HDL ratio. There were no behavioral changes, toxicity or mortality occurred up to $10 \mathrm{~g} / \mathrm{kg}$ of $\mathrm{M}$. citrifolia intake, as compared to control group ${ }^{39}$. Hepato-protective effects M. citrifolia was also affined to anti-oxidant effects in its Taiwanese fermented fruit juice at a dose range of $3-9 \mathrm{~mL} \mathrm{NJ} / \mathrm{kg} \mathrm{BW}$ on hamsters fed with a high-fat diet ${ }^{40}$.

\section{Anti-inflammatory activity}

In an in vitro study, the anti-inflammatory activity was detected in the Costa Rican M. citrifolia fruit juice by measuring its direct inhibitory activities on cyclooxygenase (COX)-1 and $-2^{41}$. The in vivo study on Tahitian M. citrifolia fruit juice showed a reduction in the induced carrageenan paw edema in rats, revealing a strong anti-inflammatory effect 
comparable to that of non-steroidal inflammatory drugs, such as acetylsalicylic acid, indomethacin and celecoxib, without side effects ${ }^{42}$. Tahitian M. citrifolia seeds oil showed topical anti-inflammatory activity by inhibiting both COX-2 and 5-LOX enzymes in an in vitro assay at concentrations of 0.5 and $1 \mathrm{mg} / \mathrm{ml}^{43}$. The topical safety of the M. citrifolia seed oil was evaluated on 49 adult volunteers using the patch test whereas topical comedogenic effect of the seed oil was studied on 23 Caucasian adolescent volunteers. Both studies were conducted for four weeks, and results indicated that the topical M.citrifolia seed oil was safe and non-comedogenic, in addition to showing a very little risk of causing allergic dermatitis which could be due to seed high fatty acids content, mainly linoleic acid ${ }^{43}$.

A randomized double-blind placebo-controlled trial using a M. citrifolia dietary supplement (U.S brand) was firstperformed on 100 women above 18 years old, however, only 80

women completed the study. The aim of the study was to find out the potential natural antiinflammatory efficacy of M.citrifolia. This study included some variables such as age, parity,body mass index, pain, menstrual blood loss, hemoglobin, packed cell volume and erythrocyte sedimentation rate before and after treatment. Patients were observed for three menstrual cycles after being exposed to $400 \mathrm{mg}$ of M. citrifolia capsules or placebo (38 in the placebo group and 42 in the M. citrifolia group) and there were no significant differences in any of the variables studied between treated and placebo group, further studies using higher doses of M. citrifolia with a larger sample size were recommended ${ }^{44}$ (Fletcher et al., 2013).

\section{Cardiovascular activity}

Noni fruit preventing arteriosclerosis, a disease related to the oxidation of low density lipoproteins (LDL). This beneficial effect could be due to the presence of lignans,phenylpropanoid dimers ${ }^{45}$ (Kamiya et al., 2004).

\section{Anti-arthritic activity}

An Indian brand of M. citrifolia fruit juice was orally administered to arthritic rats at doses $1.8 \mathrm{ml} / \mathrm{kg}$ and $3.6 \mathrm{ml} / \mathrm{kg}$, and showed a dose dependent significant reduction in paw thickness, arthritic index, secondary lesions, mononuclear infiltration and pannus formation. Similar changes were also recorded by the administration of indomethacin except for the reduction of secondary lesions. The anti-arthritic activity could be due to the presence of flavonoids and phenols ${ }^{46}$ (Saraswathi et al., 2012). Precise investigations can add a therapeutical value by specifying the chemicals owning such activities and their effective and safe doses.

\section{Anti-cancer activity}

M. citrifolia natural components are mostly reported as a natural anticancer cure where sulphated polysaccharide stops metastasis by destabilizing the interaction between glycosaminoglycan and certain proteins ${ }^{47}$ (Liu et al., 2000) while damnacanthal inhibits the formation of tumors either by interfering with the growth of ras gene activation ${ }^{48}$ (Hiramatsu et al.,1993), or by increasing apoptosis in human colorectal cancer cell lines ${ }^{49}$ (Nualsanit et al., 2012). Alizarin has an antiangiogenic effect through blocking blood circulation to malignant tumors. Limonene prevents mammary, liver, and lung cancers by stimulating thymus gland to secrete more $\mathrm{T}$ cells which destroys the carcinoma cells. Last but not the least, ursolic acid inhibits the growth of cancerous cells and induces apoptosis by modulating the body immune process ${ }^{50}$ (Lv et al., 2011).

\section{Antidiabetic activity}

Indian M. citrifolia commercial fruit juice was administered orally to induced steroid diabetic (diabetes type 2) female Wistar rats, at a dose of 1.8 and $3.6 \mathrm{ml} / \mathrm{kg}$ for 10 days. The blood 
glucose level was significantly decreased compared to control induced diabetic rats by dexamethasone. At higher oral dose $(3.6 \mathrm{ml} / \mathrm{kg}$, twice a day) M. citrifolia fruit juice had better results than rosiglitazone, but caused liver damage in rats ${ }^{51}$ (Puranik et al., 2013). On the other hand, fermented juice of South American M. citrifolia also controlled blood sugar induced diabetic rats by streptozotocin. Diabetic standard animals, treated with hypoglycemic drug, glibenclamide, while diabetic experimental animals treated with $2 \mathrm{ml} / \mathrm{kg} \mathrm{M}$. citrifolia twice a day for 20 days exhibited a significant reduction in blood glucose level of $125 \mathrm{mg} / \mathrm{dl}$ and $150 \mathrm{mg} / \mathrm{dl}$, respectively, as compared to untreated diabetic rats with fasting blood sugar of $360.0 \mathrm{mg} / \mathrm{dl}^{52}$ (Shivananda Nayak et al., 2011). Hypoglycemic activity of Tahitian M. citrifolia fruit Juice was investigated by administering the juice to male Sprague- Dawley rats at a dose of $1 \mathrm{ml} / 150 \mathrm{~g}$ body weight, twice daily for 4 weeks prior to diabetic induction using alloxan. After induction, a rise in blood glucose levels occurred but followed by a steady decline due to $M$. citrifolia juice prophylaxis against the diabetogenic agent, alloxan $^{53}$ (Horsfal et al., 2008).

\section{CONCLUSION}

The Great Morinda - Morinda citrifolia has a wide range of activity. The noni fruit juice has a high demand in the market and it is used as an alternative medicine for various kinds of diseases. Many phytochemicals were identified from different parts of the plant, among all these parts, noni fruit shows the high range of phytochemicals and activity such as anticancer, anti-oxidant, anti- inflammatory, analgesic, anti- diabetic, anti-microbial. The most important compounds identified in noni fruits are damnacanthal and scopoletin (phenolic compounds), compound named xeronine(alkaloid), caproic and caprylic acid (organic acids), ascorbic acid and provitamin A, aspartic acid, and minerals. Although many studies are done, more studies need to ensure the true potential of noni fruits.

\section{REFERENCE}

1. Hirazumi A, Furusawa E. An immunomodulatory polysaccharide-rich substance from the fruit juice of Morinda citrifolia (noni) with antitumor activity. Phyther Res. 1999;13(5):380-7.

2. European Commission Commission decision of 5 June 2003 authorising the placing on the market of "noni juice "(juice of the fruit of Morinda citrifolia L.) as a novel food ingredient under regulation (EC) No 258/97 of the European parliament and of the council. [(accessed on 11 December 2017)];Off. J. Eur. Union L 144. 2003 46:12.

3. Pino JA, Eliosbel M, Clara EQ, Déborah C. Volatile compounds in noni (Morinda citrifolia L.) at two ripening stages. Ciênc. Tecnol. Aliment. 2010;30(1):183-87.

4. Wei GJ, Chi TH, An SH. Analysis of Volatile Compounds in Noni Fruit (Morinda citrifolia L.) Juice by Steam Distillation-Extraction and Solid Phase Microextraction Coupled with GC/AED and GC/MS. Journal of Food and Drug Analysis. 2011;19(1):339.

5. D.R. Singh ,Shrawan Singh V. Shajeeda Banu. High Performance Liquid Chromatography (HPLC) analysis of different parts of Morinda citrifolia L.Intl. J. Noni Res. 2012;7 (1):55-61.

6. Bussmann RW, Lothar H, Athanassios G Jutta O, Toni MK, Feng X. Anthraquinone Content in Noni (Morinda citrifolia L.). Evidence Based Complementary and Alternative Medicine. 2013; vol 2013,1-5.

7. Bramorski A, Adriana RC, Chaiana PM, Joseane T, Tatiana M, Andréa de ASC. Total polyphenol content and antioxidant activity of commercial Noni (Morinda citrifolia L.) juice and its components. Brazilian Journal of Pharmaceutical Sciences. 2010;46(4):651 56. 
8. Heinicke RM. The Xeronine system: a new cellular mechanism that explains the health promoting action of Noni and Bromelain. Direct source publishing, Orem, Utah. 2001.

9. Samiraj R, Muthubalaji R, Rajeswari A, Ramaraj E, Subban P. Physicochemical, phytochemical and antimicrobial studies on Morinda citrifolia L. Fruits at different maturity stages. International Journal of Pharmacy and Pharmaceutical Sciences. 2012;4(5):473-76.

10. Hiramatsu T, Imoto M, Koyano T, Umezawa K. Induction of normal phenotypes in ras transformed cells by damnacanthal for Morinda citrifolia. Cancer Lett. 1993;73(2):161-6.

11. Aziz MYA, Abdul RO, Tamilselvan S, Swee KY, Wan YH, Ismail NH. Damnacanthal is a potent inducer of apoptosis with anticancer activity by stimulating p53 and p21 genes in MCF7 breast cancer. Oncology Letters. 2014;7(5):1479-84.

12. Vilas JAG, Ana RQ, Miguel AM. Damnacanthal, a noni anthraquinone, inhibits c-Met and is a potent antitumor compound against Hep G2 human hepatocellular carcinoma cells. Sci Rep. 2015;5,(8021), 1-9.

13. Hiwasaa T, Yoshiko A, Zheng C, Kazuko K, Kazuo U, Hisao I. Stimulation of ultraviolet-induced apoptosis of human fibroblast UVr-1 cells by tyrosine kinase inhibitor. FEBS Lett. 1999;444(1-2):173-6.

14. Anonymous (2015a). EGCg in Green Tea Found to Limit Activity of Breast Cancer Cells. Asia Pacific Bio Tech News. 1998;2(35):562.

15. Hornick CA, Myers A, Sadowska KH, Anthony CT, Woltering EA. Inhibition of angiogenic initiation and disruption of newly established human vascular networks by juice from Morindacitrifolia (noni). Angiogenesis. 2003;6(2):143-9.

16. Hirazumi A, Furusawa E. An immunomodulatory polysaccharide-rich substance from the fruit juice of Morinda citrifolia (noni) with antitumour activity. Phytotherapic Research.1999;13(5):380-87.

17. Liu JM, Haroun BF, Boisson VC. Analysis of the in vitro inhibition of mammary adenocarcinoma cell adhesion by sulphated polysaccharides. Anticancer Research. 2000;20(5A):3265-71.

18. Su BN, Pawlus AD, Jung HA, Keller WJ, McLaughlin JL, Kinghorn AD. Chemical constituents of fruits of Morinda citrifolia (noni) and their antioxidant activity. J Nat Prod. 2005;68(4):592-95.

19. Wang MY, Su C. Cancer preventive effect of Morinda citrifolia (Noni). Ann N Y Acad Sci. 2001;952(1):161-8.

20. Sun ZJ, Chen G, Hu X, Zhang W, Liu Y, Zhu LX. Activation of PI3K/Akt/IKKalpha/NF-kappa B signaling pathway is required for the apoptosis-evasion in human salivary adenoid cystic carcinoma: its inhibition by quercetin. Apoptosis. 2010;15(7):85063.

21. Chang TN, Jeng SD, Yi CC, Lee CY, Liao JC, Lee MM. Ameliorative Effects of Scopoletin from Crossostephium chinensis against Inflammation Pain and Its Mechanisms in Mice. Evidence Based Complementary and Alternative Medicine. 2012; vol 2012, 1-10.

22. Sang S, Kan H, Guangming L NanqunZ, Mingfu W, Jhoo JW. Citrifolinin A, a new unusual iridoid with inhibition of activator protein-1 (AP-1) from the leaves of noni (Morinda citrifolia L.). Science Direct. 2001;42(10):1823-5.

23. Hohl RJ. Monoterpenes as regulators of malignant cell proliferation. Adv Exp Med Biol. 1996;401:137-46.

24. Heinonen OP, Demetrius A, Jarmo V, Philip RT, Jussi KH, Anne MH. Prostate cancer and supplementation with alpha-tocopherol and beta-carotene: incidence and mortality in a controlled trial. J Natl Cancer Inst. 1998;90(6):440-46. 
25. Wang MY, West BJ, Jensen CJ, Diane N, SU C, Palu AK. Morinda citrifolia (noni): A literature review and recent advances in Noni research. Acta Pharmacol Sin. 2002a;23(12):1127-41.

26. Kim SH, Jun CD, Suk K, Choi BJ, Lim H, Park S. Gallic Acid Inhibits Histamine Release and Pro-inflammatory Cytokine Production in Mast Cells. Toxicol Sci. 2006;91(1):12331.

27. Satwadhar PN, Deshpande HW, Hashmi SI, Syed KA. Nutritional composition and identification of some of the bioactive components in Morinda citrifolia juice. Int J Pharm Pharm Sci. 2011;3(1):58-9.

28. Jayaraman, Sathish Kumar, Manoharan, Muthu Saravanan, Illanchezian, Seethalakshmi, 2008. Antibacterial, antifungal and tumor cell supression potential of Morinda citrifolia fruit extracts.Int. J. Integr. Biol. 3 (1), 44.

29. Atkinson, Nancy, 1956. Antibacterial substances from flowering plants. 3. Antibacterial activity of dried Australian plants by rapid direct plate test. Aust. J. Exp. Biol. 34 (1), 1726.

30. Su, B.N., Pawlus, A.D., Jung, H.A., Keller, W.J., McLaughlin, J.L., Kinghorn, A.D., 2005. Chemical constituents of the fruits of Morinda citrifolia (Noni) and their antioxidant activity. J. Nat. Prod. 68 (4), 592-595.

31. Krishnaiah, Duduku, Bono, Awang, Sarbatly, Rosalam,Anisuzzaman, S.M., 2015. Antioxidant activity and total phenolic content of an isolated Morinda citrifolia 1. methanolic extract from poly-ethersulphone (pes) membrane separator. J. King Saud University - Eng. Sci. 27 (1), 63-67. http://dx.doi.org/10.1016/j.jksues.2013.01.002.

32. Masuda, M., Murata, K., Fukuhama, A., Naruto, S., Fujita, T.,Uwaya, A., Isami, F., Matsuda, H., 2009. Inhibitory effects of constituents of Morinda citrifolia seeds on elastase and tyrosinase. J. Nat. Med. 63 (3), 267-273. http://dx.doi.org/10.1007/s11418009-0328-6.

33. Matsuda, Hideaki, Masuda, Megumi, Murata, Kazuya, Abe, Yumi, Uwaya, Akemi, 2013. Study of the anti-photoaging effect of noni (Morinda citrifolia), Melanoma - From Early Detection to Treatment

34. Matsuda, Megumi Masuda, Murata, Kazuya, Itoh, Kimihisa, Naruto, Shunsuke, Uwaya, Akemi, Isami, Fumiyuki, Hideaki, 2011. Effects of Morinda citrifolia extract and its constituents on blood fluidity. J. Tradit. Med. 28 (2), 47-54.

35. Kamiya, Kohei, Tanaka, Yohei, Endang, Hanani, Umar, Mansur, Satake, Toshiko, 2004. Chemical constituents of Morinda citrifolia fruits inhibit copper-induced low-density lipoprotein oxidation. J. Agric. Food Chem. 52 (19), 5843-5848.

36. Pak-Dek, M.S., Abdul-Hamid, A., Osman, A., Soh, C.S., 2008. Inhibitory effect of Morinda citrifolia L. on lipoprotein lipase activity. J. Food Sci. 73 (8), C595-C598. http://dx.doi.org/10.1111/j.1750-3841.2008.00929.x.

37. Nerurkar, Pratibha Vivek, Eck, Philip, 2008. Prevention of palmitic acid-induced lipotoxicity by Morinda citrifolia (noni). FASEB J. 22 (1_MeetingAbstracts), 1062-1064.

38. Palu, A.K., West, B.J., Jensen, J., 2011. Noni-based nutritional supplementation and exercise interventions influence body composition.N. Am. J. Med. Sci. 3 (12), 552-556. http://dx.doi.org/10.4297/najms.2011.3552.

39. Mandukhail, S.U., Aziz, N., Gilani, A.H., 2010. Studies on antidyslipidemic effects of Morinda citrifolia (Noni) fruit, leaves and root extracts. Lipid. Health Dis. 9 (88), 1-6. http://dx.doi.org/10.1186/1476-511x-9-88.

40. Lin, Yi-Ling, Chang, Yuan-Yen, Yang, Deng-Jye, Tzang, Bor-Show, Chen, Yi-Chen, 2013. Beneficial effects of noni (Morinda citrifolia L.) juice on livers of high-fat dietary hamsters. Food Chem. 140 (1-2), 31-38. 
41. Dussossoy, E., Brat, P., Bony, E., Boudard, F., Poucheret, P., Mertz, C., Giaimis, J., Michel, A., 2011. Characterization, anti-oxidative and anti-inflammatory effects of Costa Rican noni juice (Morinda citrifolia 1.). J. Ethnopharmacol. 133 (1), 108-115.

42. Su, B.N., Pawlus, A.D., Jung, H.A., Keller, W.J., McLaughlin, J.L., Kinghorn, A.D., 2005. Chemical constituents of the fruits of Morinda citrifolia (Noni) and their antioxidant activity. J. Nat.Prod. 68 (4), 592-595.

43. Palu, A.K., West, B.J., Jarakae, Jensen C., 2012. Noni seed oil topical safety, efficacy, and potential mechanisms of action. J. Cosmet.,Dermatol. Sci. Appl. 2 (2), 74-78.

44. Fletcher, H.M., Dawkins, J., Rattray, C., Wharfe, G., Reid, M.,Gordon-Strachan, G., 2013. Morinda citrifolia (noni) as an antiinfammatory treatment in women with primary dysmenorrhoea: a randomised double-blind placebo-controlled trial treatment in women with primary dysmenorrhoea: a randomised double-blind placebo-controlled trial. Obstet. Gynecol. Int. 2013, 1-6.

45. Anne hirazumi, Eiichi Furusawa., An immunomodulatory Polysaccharide-Rich Substance from the Fruit Juice of Morinda citrifolia (noni) with Antitumour Activity.Phytotherapy Research.1999;13(5):380-7.

46. Saraswathi, C.D., Prakash, Wagh Sagar, Kunal, P.W., 2012. Antiarthritic activity of Morinda citrifolia L. fruit juice in Complete Freund's adjuvant induced arthritic rats. J. Pharm. Res. 5 (2), 1236-1239.

47. Liu, J.M., Haroun-Bouhedja, F., Boisson-Vidal, C., 2000. Analysis of the in vitro inhibition of mammary adenocarcinoma cell adhesion by sulphated polysaccharides. Anticancer Res. 20 (5A),3265-3271.

48. Hiramatsu, T., Imoto, M., Koyano, T., Umezawa, K., 1993. Induction of normal phenotypes in ras-transformed cells by damnacanthal from Morinda citrifolia. Cancer Lett. 30 (73(2-3)), 161-166.

49. Nualsanit, T., Rojanapanthu, P., Gritsanapan, W., Lee, S.H., Lawson, D., Baek, S.J., 2012. Damnacanthal, a noni component, exhibits antitumorigenic activity in human colorectal cancer cells. J.Nutr. Biochem. 23 (8), 915-923. http://dx.doi.org/10.1016/j.jnutbio.2011.04.017.

50. Lv, Lishuang, Chen, Huadong, Ho, Chi-Tang, Sang, Shengmin, 2011.Chemical components of the roots of noni (Morinda citrifolia) and their cytotoxic effects. Fitoterapia 82 (4), 704-708.

51. Puranik, D.S., Faraz, Mohammed, Nagaraju, B., Patan Fayaz, Nazeer Ahmed, Shanthraj, Purohit, Bolouri, Ali, 2013. Preclinical evaluation of antidiabetic activity of noni fruit juice. Int. J. Bioassays 02 (02), 475-482.

52. Shivananda Nayak, B., Marshall, Julien R., Isitor, Godwin, Adogwa, Andrew, 2011. Hypoglycemic and hepatoprotective activity of fermented fruit juice of Morinda citrifolia (Noni) in diabetic rats. Evidence-Based Complement. Altern. Med. 2011, 1-5. http://dx.doi.org/10.1155/2011/875293.

53. Horsfal, A.U., Olabiyi, O.A., Osinubi, A.A., Noronha, C.C., Okanlawon, A.O., 2008. Anti diabetic effect of fruit juice of Morinda citrifolia (Tahitian Noni Juice_) on experimentally induced diabetic rats. Nigerian J. Health Biomed. Sci. 7 (2), 34-37.

54. Pazos DC, Jiménez FE, Garduño L, López VE, Cruz MC. Hypolipidemic effect of seed oil of noni (Morinda citrifolia). Nat Prod Commun. 2011;6(7):1005-8.

55. Pu HF, Wei JH, Tseng WM, Wang SW, Liu YW, Doong ML. Effects of Juice from Morinda citrifolia (Noni) on gastric emptying in male rats. Chin $\mathrm{J}$ Physiol. 2004;47(4):169-74.

56. Mahattanadul S, Ridtitid W, Nima S, Phdoongsombut N, Ratanasuwon P, Kasiwong S. Effects of Morinda citrifolia aqueous fruit extract and its biomarker scopoletin on reflux esophagitis and gastric ulcer in rats. Journal of Ethnopharmacology. 2011;134(2):243-50. 
57. Usha R, Sangeetha S, Palaniswamy M. Antimicrobial activity of a rarely known species, Morinda citrifoliaL. Ethnobotanical Leaflets. 2010;14(2012): 306-11.

58. Jainkittivong A, Butsarakamruha T, Langlais RP. Antifungal activity of Morinda citrifolia fruit extract against Candida albicans. Oral Surg Oral Med Oral Pathol Oral Radiol Endod. 2009;108(3):394-8.

59. Umezawa K. Isolation of 1-methoxy-2-foremyl-3-hydroxyanthraquinone from $M$ citrifolia and neoplasm inhibitors containing the same. Japan Kokai Tokyo Koho JP. 1992;6(87):736 (94-87,736) 1992; Appl: 92-264-311 07.

60. Nayak BS, Julien RM, Godwin I, AndrewA. Hypoglycemic and hepatoprotective activity of fermented fruit juice of Morinda citrifolia (Noni) in diabetic rats. Evidence Based Complementary and Alternative Medicine. 2011; 2011, 1-5.

61. Joseph B. Pride publishing, noni: Polynesia's natural pharmacy. 1997; P 13.

62. Wang MY, Su C. Cancer preventive effect of Morinda citrifolia (Noni). Ann N Y Acad Sci. 2001;952(1):161-8.

63. Sun ZJ, Chen G, Hu X, Zhang W, Liu Y, Zhu LX. Activation of PI3K/Akt/IKKalpha/NF-kappa B signaling pathway is required for the apoptosis-evasion in human salivary adenoid cystic carcinoma: its inhibition by quercetin. Apoptosis. 2010;15(7):85063.

64. Chang TN, Jeng SD, Yi CC, Lee CY, Liao JC, Lee MM. Ameliorative Effects of Scopoletin from Crossostephium chinensis against Inflammation Pain and Its Mechanisms in Mice. Evidence Based Complementary and Alternative Medicine. 2012; vol 2012, 1-10.

65. Sang S, Kan H, Guangming L NanqunZ, Mingfu W, Jhoo JW. Citrifolinin A, a new unusual iridoid with inhibition of activator protein-1 (AP-1) from the leaves of noni (Morinda citrifolia L.). Science Direct. 2001;42(10):1823-5.

66. Hohl RJ. Monoterpenes as regulators of malignant cell proliferation. Adv Exp Med Biol. 1996;401:137-46.

67. Heinonen OP, Demetrius A, Jarmo V, Philip RT, Jussi KH, Anne MH. Prostate cancer and supplementation with alpha-tocopherol and beta-carotene: incidence and mortality in a controlled trial. J Natl Cancer Inst. 1998;90(6):440-46.

68. Wang MY, West BJ, Jensen CJ, Diane N, SU C, Palu AK. Morinda citrifolia (noni): A literature review and recent advances in Noni research. Acta Pharmacol Sin. 2002a;23(12):1127-41.

69. Kim SH, Jun CD, Suk K, Choi BJ, Lim H, Park S. Gallic Acid Inhibits Histamine Release and Pro-inflammatory Cytokine Production in Mast Cells. Toxicol Sci. 2006;91(1):12331.

70. Nualsanit T, Pleumchitt R, Wandee G, Leea SH, Darunee L, Seung JB. Damnacanthal, A noni component, exhibits anti-tumorigenic activity in human colorectal cancer cells. J Nutr Biochem. 2012;23(8):915-23.

71. Gupta RK, Banerjee A, Pathak S, Sharma C, Singh N. Induction of mitochondrialmediated apoptosis by Morinda citrifolia (noni) in human cervical cancer cells. Asian Pac J Cancer Prev. 2013;14(1):237.

72. Karamcheti SA, Satyavati D, Subramanian NS, Pradeep HA, Pradeep KC, Deepika PG. Chemoprotective effect of ethanolic extract of Morinda citrifolia against Cisplatin induced nephrotoxicity. The Pharma Innovation. 2014;3(1): 84-91.

73. Kumar GS. The effect of Noni (Morinda citrifolia L.) in type 2 diabetes mellitus in inadequately controlled patients. Noni Cli Res J. 2007;1(1-2):20-4. 